\title{
Morphology and Volume of Maxillary Canine Pulp Cavity for Individual Age Estimation in Forensic Dentistry
}

\author{
Morfología y Volumen de la Cavidad de Pulpa del Canino Maxilar \\ para la Estimación de la Edad Individual en Odontología Forense
}

\author{
Li Bing'; Xiu-Ping Wu¹; Hong-Shangguan²; Wu Xiao' ${ }^{1}$ \& Ke-Ming Yun ${ }^{3}$
}

LI, B.; XIU-PING, W.; HONG-SHANGGUAN; WU, X. \& KE-MING, Y. Morphology and volume of maxillary canine pulp cavity for individual age estimation in forensic dentistry. Int. J. Morphol., 35(3):1058-1062, 2017.

SUMMARY: Age estimation plays a very important role in individual recognition in forensic dentistry. Morphological data of 3D pulp cavity of maxillary canines were acquired by oral and craniofacial CT scans. In accordance with inclusion criteria, CT data of 103 patients (51 males and 52 females) were collected at the Department of Radiology, Stomatological Hospital, Shanxi Medical University, China from September 2015 to August 2016. Mimics 17.0 software was used to measure pulp volume of maxillary canines and tooth volume, and to calculate the ratio of pulp volume/tooth volume. SPSS 16.0 software was utilized to analyze and establish database. Linear regression analysis was applied to process data and to establish a linear regression equation for individual age: $\mathrm{Y}=69.137-621.200$ (pulp volume/tooth volume), $\mathrm{R}=0.544$. Subjects were grouped according to gender, deriving the inferred function of male age: $\mathrm{Y}=64.333-468.811$ (pulp volume/tooth volume), $\mathrm{R}=0.435$; the inferred function of female age: $\mathrm{Y}=76.445-843.186$ (pulp volume/tooth volume), $\mathrm{R}=0.691$. The ratio of pulp volume to tooth volume can be used to infer individual age, and can provide a new method and pathway for individual recognition in forensic dentistry.

KEY WORDS: Forensic dentistry; Maxillary canines; Pulp cavity morphology and volume; Identification; Age estimation.

\section{INTRODUCTION}

Individual recognition mainly includes the inferred age, sex, and height. Individual recognition has a high application value in clinical practice of forensic dentistry. For example, it is necessary to confirm the age of the individual for legal reasons (Star et al., 2011; Bing et al., 2013; Tardivo et al., 2014). In the case of major natural disasters or criminal case investigation, individual recognition can provide the basis for the identification of the body and narrow the scope of identification. The tooth is the hardest part of the body, it can resist the physical, chemical and time effects, and can be saved for a long time after death. The dental age can be slightly influenced by nutrition, environment and life style. Thus, the inference of dental age has high reliability and unique significance in individual recognition (Someda et al., 2009; Aboshi et al., 2010; Tardivo et al., 2011). With age, secondary dentin and reparative dentin continue to deposit, so many scholars select secondary dentin deposition as an age-related research indicator, but this study can only be carried out on the corpse (Bommannavar \& Kulkarni, 2015; Chopra et al., 2015; Kaur, et al., 2015; Klumb et al., 2016). To make up for this limitation, on the basis of previous studies, we used oral and craniofacial CT to take three-dimensional (3D) images of maxillary canines, selected the ratio of pulp volume (PV) to tooth volume (TV) (PV/ $\mathrm{TV}$ ) as an indicator to infer individual age, and deduced the equation of related function for individual age inference by using 3D method so as to provide theoretical guidance for the follow-up clinical work of forensic medicine.

\section{MATERIAL AND METHOD}

CT images of 103 patients (51 males and 52 females) were selected from the Department of Radiology, Stomatological Hospital, Shanxi Medical University, China,

\footnotetext{
${ }^{1}$ Stomatology Hospital, Shanxi Medical University, Taiyuan, China.

${ }^{2}$ School of electronic information engineering, Taiyuan University of Science and Technology, Taiyuan, China.

${ }^{3}$ School of Forensic Medicine, Shanxi Medical University, Taiyuan, China.

Funding: Doctoral Fund of Shanxi Medical University, No. 03201428.
} 


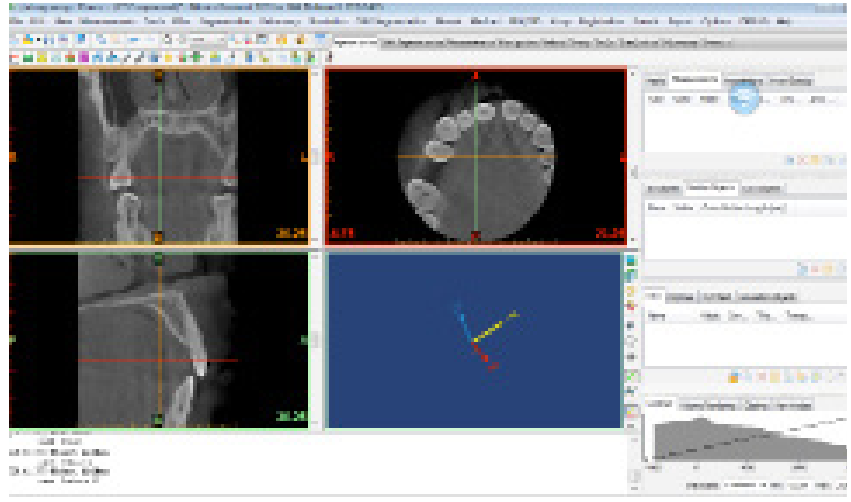

Fig.1. Interface after data import.

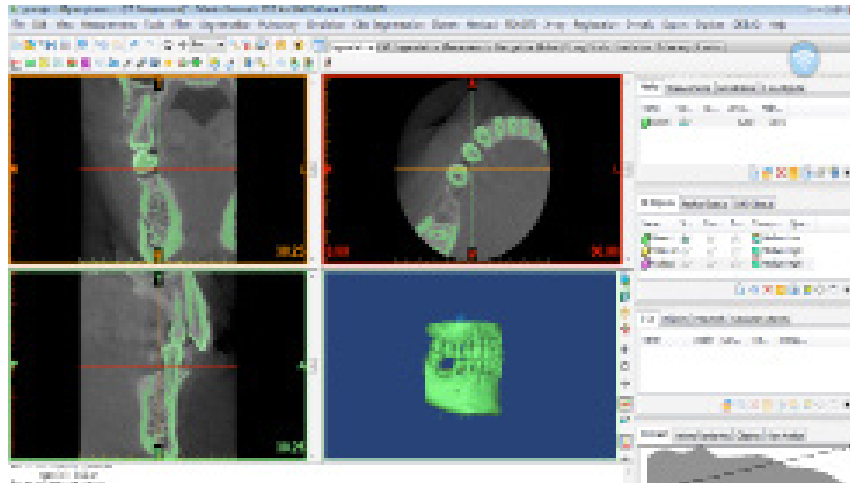

Fig. 2. Three-dimensional reconstruction of dental arch shape.

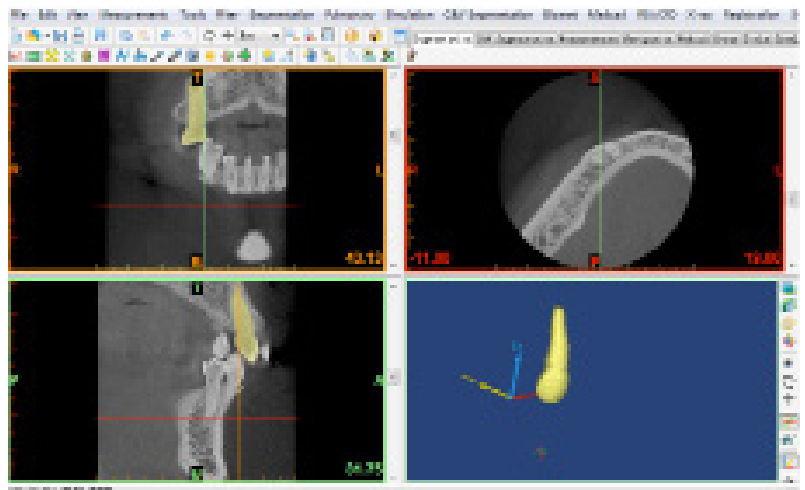

Fig. 3. Three-dimensional reconstruction of the maxillary canines.

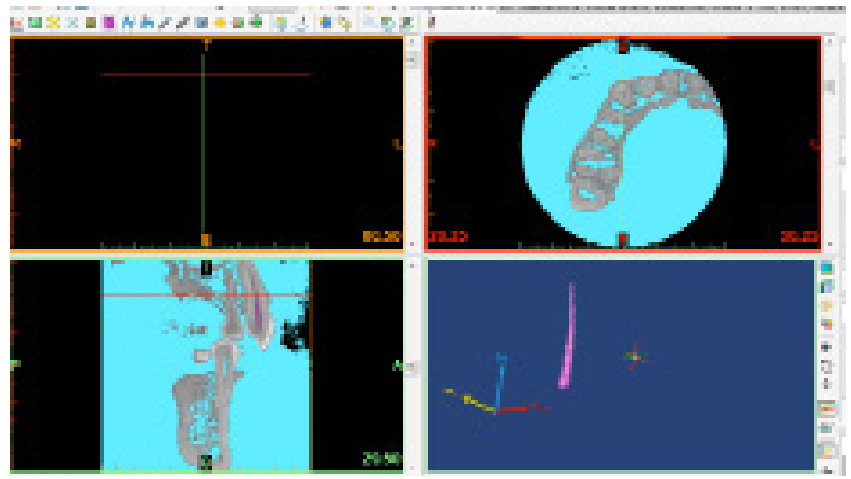

Fig. 4. Three-dimensional reconstruction of the pulp cavity. from September 2015 to August 2016. Inclusion criteria: (1) Clear and complete teeth; (2) completely developed maxillary canine root tip, no abrasion, no caries, no dental treatment history, no calcification in the pulp cavity; (3) no history of orthodontics and orthognathic surgery. Exclusion criteria: (1) Oral and maxillofacial deformities and other systemic diseases affecting oral and maxillofacial development; (2) history of orthodontic treatment or trauma. Measurement indexes : PV/TV.

Instruments and software. Oral and craniofacial CT (MCT-1)(Morita, Japan); Mimics 17.0 software; SPSS 16.0 software.

Harvesting CT images and importing CT image data. We recorded the basic information of each CT image, including name, sex, date of birth, age, and date of image shooting. CT image data were imported after being converted to DICOM format (Fig. 1).

3D reconstruction of dental arch. The $3 \mathrm{D}$ reconstruction of the dental arch was completed according to the threshold of the teeth (Fig. 2).

3D reconstruction of maxillary canine shape. In accordance with morphology and location of maxillary canines, the erasure, regional growth, and patching of the canines, adjacent teeth and skeleton were performed to complete the $3 \mathrm{D}$ reconstruction of maxillary canines and volume calculation (Fig. 3).

3D reconstruction of pulp cavity of maxillary canines. According to threshold range of the pulp cavity, regional growth, patching and erasure of the pulp cavity of maxillary canines were conduced to finish the 3D reconstruction of pulp cavity of maxillary canines and volume calculation (Fig. 4).

Statistical analysis. SPSS 16.0 software was used to analyze data and establish database. Linear regression method was utilized to establish age discrimination function.

\section{RESULTS}

Descriptive analysis of measurement indexes. Mimics 17.0 software was used to measure PV and TV and to calculate the PV/TV (Table I).

Establishment of age estimation equation. SPSS 16.0 software was applied to analyze and establish database. Linear regression analysis was employed to process data 
(Tables II, III) and to establish a linear regression equation for individual age: $\mathrm{Y}=69.137-621.200 \mathrm{X}(\mathrm{X}=\mathrm{PV} / \mathrm{TV}), \mathrm{P}<0.001$, $\mathrm{R}=0.544$. The linear regression equation was statistically significant. When PV/TV changed 0.01 , the age averagely changed $6.212 ; \mathrm{R} 2=29.6 \%$; these suggested that age changes of $29.6 \%$ can be explained by PV/TV.
Establishment of male and female age estimation equations. Subjects were grouped according to sex, and analyzed using linear regression analysis, deriving the inferred function of male age: $\mathrm{Y}=64.333-468.811$ (PV/TV), $\mathrm{R}=0.435$; the inferred function of female age: $\mathrm{Y}=76.445-843.186(\mathrm{PV} /$ $\mathrm{TV}), \mathrm{R}=0.691$. Results suggested that male and female linear regression equations were statistically significant.

Tables I. Statistical description of measurement results.

\begin{tabular}{lccccc}
\hline & $\mathrm{N}$ & Minimum & Maximum & Mean & Std. Deviation \\
\hline $\mathrm{PV} / \mathrm{T}$ (males) & 51 & .013222 & .073243 & .04194985 & .012060164 \\
$\mathrm{PV} / \mathrm{T}$ (females) & 52 & .025720 & .074363 & .03993891 & .010596221 \\
\hline
\end{tabular}

Table II Linear regression analysis of all samples.

\begin{tabular}{|c|c|c|c|c|}
\hline Model & Unstandardized Coefficients & Standardized & $\mathrm{t}$ & Sig. \\
\hline & B $\quad$ Std. Error & $\begin{array}{l}\text { Coefficients } \\
\text { Beta }\end{array}$ & & \\
\hline $1 \quad \begin{array}{l}\text { (Constant) } \\
\text { ratio }\end{array}$ & $\begin{array}{c}69.137 \\
-621.200\end{array}$ & -544 & $\begin{array}{l}17.093 \\
-6.521\end{array}$ & $\begin{array}{l}.000 \\
.000\end{array}$ \\
\hline
\end{tabular}

Table III Correlation coefficient of linear regression equation.

\begin{tabular}{ccccc}
\hline Model & $\mathrm{R}$ & $\mathrm{R}$ Square & Adjusted R Square & Std. Error of the Estimate \\
\hline 1 & $.544^{\mathrm{a}}$ & .296 & .289 & 10.90419 \\
\hline
\end{tabular}

\section{DISCUSSION}

Teeth are the hardest parts of the human body, can resist the influence of various physical and chemical factors, and can provide protection for the research of individual recognition (Abreu-Glowacka et al., 2011; Wu et al., 2014). Gustafson first proposed in 1950 to use six characteristic changes of age-related teeth for age estimation, but there were some defects in the age structure and statistical inference of the samples. Subsequently, many scholars use dentin translucency, cementum ring structure, amino acid racemization, and modified Gustafson method for age estimation (Singh et al., 2014; Shrigiriwar \& Jadhav, 2013; Vandevoort et al., 2004; Telang et al., 2014; Gilmore \& Grote, 2012). However, these methods are complicated, require professionals to use special equipment and to spend a lot of time and financial resources, and sometimes even need to pull out the teeth. It is destructive and cannot be achieved in living beings, and is sometimes not accepted in ethics, religion, and scientific research. Some scholars also carry on the age estimation according to the tooth attrition degree, but this method is affected by diet and individual habits, subjective, with high error rate. With the development of medical imaging, oral and maxillofacial CT can be used for 3D reconstruction and axial imaging. The scanning time is short; the resolution is high; and the reconstructed image is clear. CT provides a new method and thought for the individual recognition of forensic dentistry (Jagannathan et al., 2011; Cantekin et al., 2013). In this study, the maxillary canine was chosen as the sample, because the length of stay in the mouth was longer compared with other teeth. The canine is a relatively larger single root canal tooth, which is easier to operate compared with other single or multiple root canal teeth. The canine has special position and function, so its wear in the mouth is relatively light (Tardivo et al., 2011).

CT image data were imported in the software after being converted to DICOM format for statistical analysis. 
This not only overcomes the overlapping of the traditional $2 \mathrm{D}$ image data, but also solves the error caused by manual measurement; and the operation is simple and quick. We balanced the sample size between males and females in various age groups to avoid bias caused by a large number of subjects at a certain age.

On the basis of previous studies, this study used oral and craniofacial CT to take 3D images of maxillary canines, selected PV/TV ratio as an indicator to infer individual age. Nevertheless, Ge et al. (2015), proposed that secondary dentin deposition directly caused a reduction in pulp cavity volume, and confirmed that the pulp cavity volume chosen as the research index was more scientific and reliable than the choice of $\mathrm{PV} / \mathrm{TV}$ ratio. This study analyzed $\mathrm{PV} / \mathrm{TV}$ ratio using linear regression analysis according to sex grouping, and analyzed PV as a research index. Our results demonstrated that when PV/TV ratio was used as an index, a linear regression equation for individual age was established: $\mathrm{Y}=69.137-621.200$ (PV/TV), $\mathrm{R}=0.544$; the inferred function of male age: $\mathrm{Y}=64.333-468.811$ (PV/TV), $\mathrm{R}=0.435$; the inferred function of female age: $\mathrm{Y}=76.445-843.186(\mathrm{PV} /$ TV), $R=0.691$. Above results were significantly different. When PV was used as an index, $\mathrm{R}=0.450 ; \mathrm{R}=0.441$ in males; $\mathrm{R}=0.678$ in females. Our results suggested that for age estimation, the effects of PV/TV ratio as the index were better than that of PV as the index. In summary, PV/TV ratio can be used to estimate individual age, and provides a new method and means for individual recognition in forensic dentistry.

LI, B.; XIU-PING, W.; HONG-SHANGGUAN; WU, X. \& KEMING,Y. Morfología y volumen de la cavidad de pulpa del canino maxilar para la estimación de la edad individual en odontología forense. Int. J. Morphol., 35(3):1058-1062 2017.

RESUMEN: La estimación de la edad juega un papel importante en el reconocimiento individual en la odontología forense. Los datos morfológicos de la cavidad pulpar tridimensional de los caninos maxilares fueron adquiridos por tomografía computarizada oral y craneofacial. De acuerdo con los criterios de inclusión, se recolectaron datos de 103 pacientes (51 hombres y 52 mujeres) en el Departamento de Radiología del Hospital de Estomatología de la Universidad de Medicina de Shanxi, desde septiembre de 2015 hasta agosto de 2016. Se utilizó el software Mimics 17.0 para medir el volumen de pulpa de los caninos maxilares y el volumen del diente, además, se calculó la relación entre el volumen de la pulpa y el volumen del diente. Se utilizó el software SPSS 16.0 para analizar y establecer las bases de datos. El análisis de regresión lineal se aplicó a los datos del proceso y para establecer la edad individual se aplicó una ecuación de regresión lineal: $\mathrm{Y}=$ 69.137-621.200 (volumen de la pulpa / volumen del diente), $\mathrm{R}=$ 0.544. Los sujetos se agruparon según el sexo, derivando la función inferida de la edad masculina: $\mathrm{Y}=64.333-468.811$ (volumen de la pulpa / volumen del diente), $\mathrm{R}=0.435$; La función inferida de la edad de la mujer: $\mathrm{Y}=76.445-843.186$ (volumen de la pulpa / volumen del diente), $\mathrm{R}=0.691$. La relación entre el volumen de la pulpa y el volumen del diente puede usarse para inferir la edad individual y puede proporcionar un nuevo método y forma para el reconocimiento individual en la odontología forense.

PALABRAS CLAVE: Odontología forense; Caninos maxilares; Morfología y volumen de la cavidad pulpar; Identificación; Estimación de edad.

\section{REFERENCES}

Aboshi, H.; Takahashi, T. \& Komuro, T. Age estimation using microfocus $\mathrm{X}$-ray computed tomography of lower premolars. Forensic Sci. Int., 200(1-3):35-40, 2010.

Abreu-Glowacka, M.; Zaba, C.; Koralewska-Kordel, M.; Michalak, E.; Lorkiewicz-Muszynska, D. \& Tezyk, A. DNA studies performed on a mummified body from Forensic Department Museum of Poznan University of Medical Sciences. Arch. Med. Sadowej. Kryminol., 61(2):181-7, 2011.

Bing, L.; Wu, X.; Feng, Y.; Wang, Y. \& Liu, H. Application of X-ray cephalometric analysis of adolescents in medicolegal investigation. Life Sci. J., 10(3):2450-5, 2013.

Bommannavar, S. \& Kulkarni, M. Comparative study of age estimation using dentinal translucency by digital and conventional methods. $J$. Forensic Dent. Sci., 7(1):71-5, 2015.

Cantekin, K.; Sekerci, A. E. \& Buyuk, S. K. Dental computed tomographic imaging as age estimation: morphological analysis of the third molar of a group of Turkish population. Am. J. Forensic Med. Pathol., 34(4):357-62, 2013

Chopra, V.; Thodasam, G.; Ahmad,Z. H.; Singh, S.; Rajawat, I. \& Gupta, S. Conventional versus digital approach for measuring dentin translucency in forensic age estimation. J. Nat. Sci. Biol. Med., 6(1):139-43, 2015.

Ge,Z. P.; Ma, R. H.; Li, G.; Zhang, J. Z. \& Ma, X. C. Age estimation based on pulp chamber volume of first molars from cone-beam computed tomography images. Forensic Sci. Int., 253:133.e1-7, 2015.

Gilmore, C. C. \& Grote, M. N. Estimating age from adult occlusal wear: a modification of the miles method. Am.J. Phys. Anthropol., 149(2):181$92,2012$.

Jagannathan, N.; Neelakantan, P.; Thiruvengadam, C.; Ramani, P.; Premkumar, P.; Natesan, A.; Herald, J. S. \& Luder, H. U. Age estimation in an Indian population using pulp/tooth volume ratio of mandibular canines obtained from cone beam computed tomography. J. Forensic Odontostomatol., 29(1):1-6, 2011.

Kaur, P.; Astekar, M.; Singh, J.; Arora, K. S. \& Bhalla, G. Estimation of age based on tooth cementum annulations: A comparative study using light, polarized, and phase contrast microscopy. J. Forensic Dent. Sci., 7(3):215-21, 2015.

Klumb, K.; Matzenauer, C.; Reckert, A.; Lehmann, K. \& Ritz-Timme, S. Age estimation based on aspartic acid racemization in human sclera. Int. J. Legal Med., 130(1):207-11, 2016.

Shrigiriwar, M. \& Jadhav, V. Age estimation from physiological changes of teeth by Gustafson's method. Med. Sci. Law, 53(2):67-71, 2013.

Singh, N.; Grover, N.; Puri, N.; Singh, S. \& Arora, S. Age estimation from physiological changes of teeth: A reliable age marker? J. Forensic Dent. Sci., 6(2):113-21, 2014.

Someda, H.; Saka, H.; Matsunaga, S.; Ide, Y.; Nakahara, K.; Hirata, S. \& Hashimoto, M. Age estimation based on three-dimensional measurement of mandibular central incisors in Japanese. Forensic Sci. Int., 185(1-3):110-4, 2009.

Star, H.; Thevissen, P.; Jacobs, R.; Fieuws, S.; Solheim, T. \& Willems, G. Human dental age estimation by calculation of pulp-tooth volume ratios 
LI, B.; XIU-PING, W.; HONG-SHANGGUAN; WU, X.; \& KE-MING, Y. Morphology and volume of maxillary canine pulp cavity for individual age estimation in forensic dentistry. Int. J. Morphol., 35(3):1058-1062, 2017.

yielded on clinically acquired cone beam computed tomography images of monoradicular teeth. J. Forensic Sci., 56 Suppl. 1:S77-82, 2011.

Tardivo, D.; Sastre, J.; Catherine, J. H.; Leonetti, G.; Adalian, P. \& Foti, B. Age determination of adult individuals by three-dimensional modelling of canines. Int. J. Legal Med., 128(1):161-9, 2014.

Tardivo, D.; Sastre, J.; Ruquet, M.; Thollon, L.; Adalian, P.; Leonetti, G. \& Foti, B. Three-dimensional modeling of the various volumes of canines to determine age and sex: a preliminary study. J. Forensic Sci., 56(3):766-70, 2011.

Telang, L. A.; Patil, K. \& Mahima, V. G. Age estimation of an Indian population by using the Kim's scoring system of occlusal tooth wear. $J$. Forensic Dent. Sci., 6(1):16-24, 2014

Vandevoort, F. M.; Bergmans, L.; Van Cleynenbreugel, J.; Bielen, D. J.; Lambrechts, P.; Wevers, M.; Peirs, A. \& Willems, G. Age calculation using X-ray microfocus computed tomographical scanning of teeth: a pilot study. J. Forensic Sci., 49(4):787-90, 2004.

Wu, X. P.; Han, J. N.; Fen, P.; Wang, Y. J. \& Bing, L. Application of palatal rugae morphology in forensic identification. Int. J. Morphol., 34(2):510-3, 2016.

\author{
Correspondence author: \\ Dr. Xiu-Ping Wu \\ Stomatology Hospital \\ Shanxi Medical University \\ 63 Xinjian Road, Taiyuan 030001 \\ CHINA
}

E-mail: libing-1975@163.com

Received: 18-03-2017

Accepted: 05-05-2017 